\title{
ІНТЕНСИФІКАЦІЯ ПРОЦЕСУ ЕКСТРАГУВАННЯ В ТЕХНОЛОГІЯХ УТИЛІЗАЦЇ̈ ВІДХОДІВ ХАРЧОВИХ ТА ОЛІЙНИХ ВИРОБНИЦТВ
}

\author{
Терзісв С.Г., д-р техн. наук, доцент, \\ Ружицька Н.В., канд. техн. наук, асистент, Щербич М., аспірант, Альхурі Юсеф, канд. техн. наук \\ Одеська національна академія харчових технологій, м. Одеса
}

У статті розглядаються питання утилізації відходів олійної, харчоконцентратної, консервної промисловості. Пропонується задіяти технологї екстрагування для вилучення цінних компонентів, які залишаються у відходах після виробництва основного продукту. Розглянуто можливість вилучення олій з лушпиння кави та макухи амаранту. Також досліджено екстрагування водо- та лугорозчинних фракцій з макухи амаранту як стадія вилучення иінного білка. Розглянуто екстрагування водорозчинних компонентів зі свіжих яблучних вичавок - фруктово-ягідних відходів. Інтенсифікувати процес екстрагування запропоновано иляхом підведення енергї у вигляді мікрохвильового випромінення, яке викликає у структурах сировини явище бародифузї̈, та забезпечення режиму кипіння екстрагенту, який організує постійний контакт свіжих пориій екстрагенту з сировиною. Для збереження термолабільних речовин та запобігання денатурації білка в екстракторі кипіння здійснюється у вакуумі. Показано результати вилучення олії та спирторозчинних компонентів лушпиння кави та макухи амаранту. Отримано кінетичні криві процесу екстрагування макухи амаранту водою та лужним розчином в умовах дї мікрохвильового поля та вакууму. Наведено порівняння кінетики екстрагування лугорозчинної фракиії макухи амаранту із застосуванням адресної доставки енергії та при традиційному енергопідведенні. Показано значну інтенсифікацію процесу. Визначено питомі енерговитрати процесу. Отримано кінетичні криві процесу екстрагування яблучних вичавок водою при різних гідромодулях. Встановлено відсоток сухих речовин твердої фази, який переходить до екстракту. Визначено питомі енерговитрати на прочесс одержання екстракту. Одержано продукт з аромтом яблук та вираженими желюючими властивостями.

Ключові слова: відходи, макуха амаранту, мікрохвильове екстрагування, яблучні вичавки, вакуум.

Вступ. Нераціональне використання харчової сировини створює суттєву екологічну проблему утилізації великих обсягів відходів. Проте такі відходи можуть містити значну кількість цінних харчових компонентів: білків, олій, клітковини, пігментів. Після екстрагування або пресування з сировини вилучається головним чином лише певна група компонентів. Так при виробництві розчинної кави з зерен вилучаються лише водорозчинні речовини, у виробництві олій - тільки ліпіди та жиророзчинні речовини, після віджиму фруктових соків залишаються вичавки, які містять пектини, цукри, вітаміни, поліфеноли [1 - 3]. Одним зі шляхів переробки харчових відходів є екстрагування цільових компонентів різними екстрагентами. Це може бути вода, етанол, полярні розчинники. Відомі дослідження з екстрагування олії та водорозчинних компонентів зі шламу кави із застосуванням мікрохвильового підведення енергії [2]. Також проводились досліди 3 екстрагування кавового лушпиння етанолом та водою які показали високий вихід кофеїну [4], встановлено жирнокислотний склад олії [5]. Поряд із адресною доставкою енергії до мікро- та наноструктур рослинної сировини та виникненням явища бародифузіі, інтенсифікація процесу екстрагування відбувається за рахунок турбулізації потоку екстрагенту, яка забезпечує постійний контакт свіжих порцій екстрагенту з твердою фазою. Досягти режиму кипіння екстрагенту при низьких температурах можна за рахунок створення в екстракторі вакууму. Використання вакууму одночасно з адресною доставкою енергії показало обнадійливі результати в дослідах з ефіроолійною сировиною, сухими сливовими вичавками, кавовим лушпинням [4].

Формулювання завдань досліджень. Для екстрагування ряду компонентів, особливо таких термолабільних, як білки, принципово важливі низькі температури процесу. Зменшення контакту олій, багатих ненасиченими жирними кислотами та інших чутливих до окиснення сполук з повітрям також позитивно впливає на якість кінцевого продукту. Завданням досліджень $є$ збільшення виходу цільових компонентів 3 відходів харчових та олійних виробництв, зменшення питомих енерговитрат зі збереженням термолабільних сполук.

Об'скти досліджень. В якості олієвмісних відходів розглядалися макуха амаранту, шлам та лушпиння кави. Макуха амаранту після вилучення олії пресуванням може містити від 2 до 8 \% жирів, 15...22\% білків, $57 \ldots 78 \%$ вуглеводів [3,6]. Білок амаранту за амінокислотним складом наближається до ідеального білка $[3,7]$. Вміст жирів у дослідних зразках складав $2,1 \ldots 2,8$ \%. Таким чином, 3 даних відходів можливо вилучити залишки олії, білок, крохмаль та клітковину. Шлам та лушпиння кави містять цінні олії, які можуть бути вилучені екстрагуванням. Якщо шлам кави містить $16 . .20 \%$ олії, то лушпиння - близько 3 \%, за жирнокислотним складом ці олії значно відрізняються [5]. 
3 відходів фруктово-ягідної сировини в якості об’єкту дослідження було обрано яблучні вичавки, оскільки в Україні саме яблуня на першому місці за площами вирощування та врожайністю. Відходи переробки

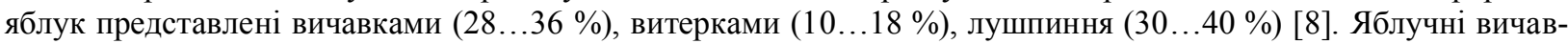
ки на $95 \%$ складаються зі шкірки та м'якоті [1]. Проте на підприємствах свіжі вичавки не зберігаються,

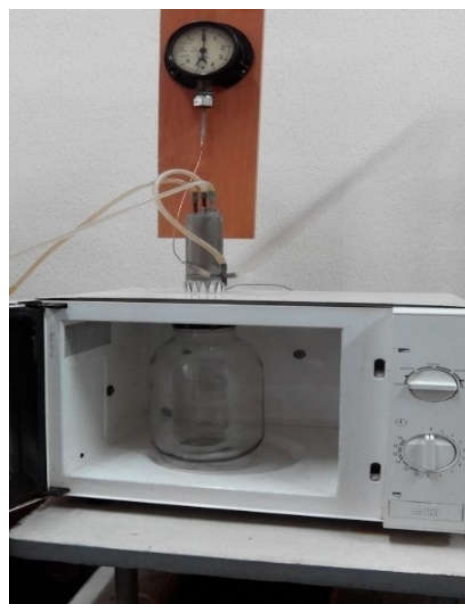

Рис.1 - Мікрохвильовий вакуум-екстрактор

оскільки швидко починається процес бродіння. В сухих вичавках міститься близько $44 \%$ безазотистих екстрактивних речовин, $6 \%$ цукру, $28 \%$ клітковини, до $18 \%$ пектину, 8 \% білку [9]. Свіжі вичавки містять 0,7 \% білка, 1,3 \% ліпідів, 9,1 \% цукрів, 2,5 \% пектинів [1]. На сьогоднішній день відходи переробки яблук пропонують додавати до комбікормів [8], в якості армуючого компоненту у пакувальних матеріалах [10], у вигляді порошків як добавку до хлібобулочних, кондитерських виробів, харчоконцентратів, на основі пектиновмісних екстрактів розроблено рецептури функціональних напоїв [11].

Результати досліджень. Екстрагування цільових компонентів 3 відходів проводили у мікрохвильовому вакуум-екстракторі періодичної дії (рис.1), який складається 3 мікрохвильової камери, конденсатору та ваку-

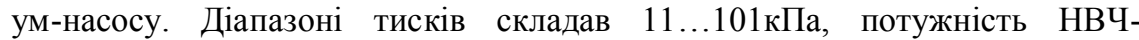
інтенсифікатора становила $120 \ldots 250$ Вт. Об'єм продукту, який завантажувався у камеру складав $1 \ldots 2$ л.

Для екстрагування в умовах заданої постійної температури без дії мікрохвильового поля була використана водяна баня лабораторна ВБ-2.

Проведено порівняння ефективності вилучення сухих речовин етанолом з макухи амаранту, шламу та лушпиння кави (табл. 1). Температура процесу дорівнювала температурі кипіння етанолу, гідромодуль складав 1:9.

Таблиия 1

Вихід сухих речовин з олісвмісних відходів при мікрохвильовому екстрагуванні етанолом в умовах атмосферного тиску

\begin{tabular}{|l|c|c|c|c|}
\hline \multicolumn{1}{|c|}{ Відходи } & $\begin{array}{c}\text { Температура, } \\
{ }^{\circ} \mathrm{C}\end{array}$ & $\begin{array}{c}\text { Кінцева концентрація } \\
\text { екстракту, \% }\end{array}$ & $\begin{array}{c}\text { Вміст олії, } \\
\%\end{array}$ & $\begin{array}{c}\text { Вилучена частка від маси } \\
\text { вихідної сировини, \% }\end{array}$ \\
\hline Шлам кави & $70 \ldots 75$ & 1,3 & $16 \ldots 20$ & 11,05 \\
\hline Лушпиння кави & $70 \ldots 75$ & 0,81 & 3 & 5,14 \\
\hline Макуха амаранту & $70 \ldots 75$ & 1,14 & $2,1 \ldots 2,8$ & 9,69 \\
\hline Макуха амаранту & 45 & 0,8 & $2,1 \ldots 2,8$ & 3,2 \\
\hline
\end{tabular}

Знаючи вихідний вміст олії в сировині, можна зробити висновок, що до екстракту з лушпиння кави та макухи амаранту переходять не тільки олія а й інші спирторозчинні компоненти. Для виділення чистої олії необхідне додаткове розділення таких екстрактів. Крім того, після проведення аналізу збідненої макухи амаранту встановлено, що при $45{ }^{\circ} \mathrm{C}$ етанолом було вилучено близько 50 \% олії. Таким чином, за температур, які не викликають денатурацію білків амаранту, з 1 кг макухи вилучається не більше $15 \ldots 16$ г олії. Доцільність такої переробки потребує додаткових економічних розрахунків. Це стосується й лушпиння кави.

Після вилучення олії (знежирення) проводились дослідження з екстрагування водо- та лугорозчинної фракції з макухи амаранту. Щоб запобігти денатурації білків та клейстеризації крохмалю, досліди проводились за температури $40 \ldots 45^{\circ} \mathrm{C}$ та тиску 11 кПа. Гідромодуль складав $1: 9$. Результати наведено на рис. 2

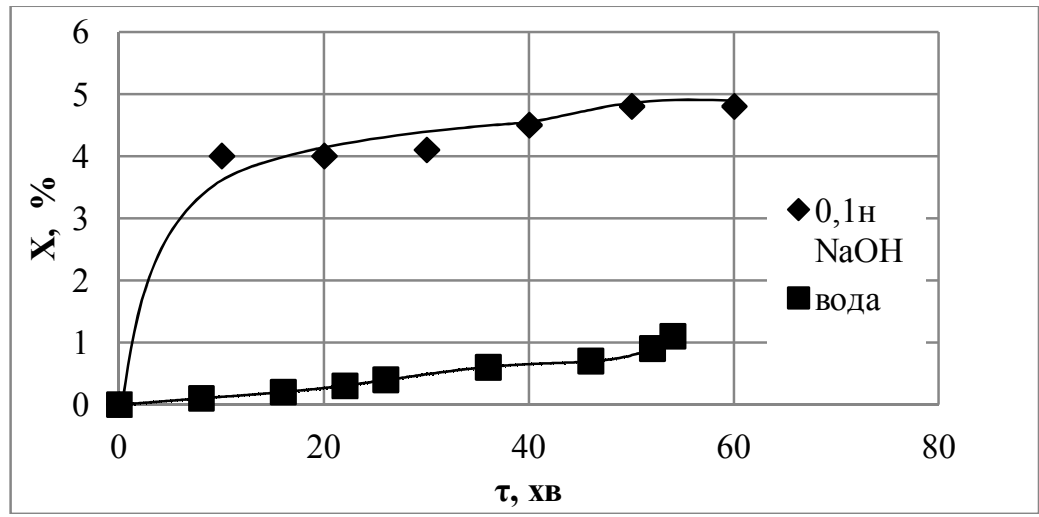

Рис. 2 - Порівняння кінетики вилучення сухих речовин з макухи амаранту різними екстрагентами 
3 графіків видно, що при екстрагуванні лужним розчином основне зростання концентрації сухих речовин відбувається протягом перших 10 хвилин. Найменша швидкість вилучення сухих речовин спостерігалась у дослідах з водою.

Встановлено, який відсоток маси твердої фази макухи амаранту переходить в екстрагент (табл. 2).

Таблиия 2

Вихід сухих речовин з макухи амаранту при екстрагуванні різними екстрагентами при $40 \ldots 45^{\circ} \mathrm{C}$

\begin{tabular}{|l|c|c|}
\hline Екстрагент & $\begin{array}{c}\text { Кінцева концентрація } \\
\text { екстракту, \% }\end{array}$ & $\begin{array}{c}\text { Частка від маси вихідної } \\
\text { сировини, яка переходить у екстрагент, \% }\end{array}$ \\
\hline 0,1 розчин $\mathrm{NaOH}$ & 4,8 & 48 \\
\hline Вода & 1,1 & 11 \\
\hline Етанол & 0,8 & 3,2 \\
\hline
\end{tabular}

У лугорозчинній фракції близько 70 \% сухих речовин складає крохмаль. Вода вилучає альбумін, цукри, сапоніни. Таким чином всі одержані екстракти потребують подальшого розділення на цільові компоненти фізичними або хімічними способами.

Також визначався вплив попереднього знежирення сировини на вихід водорозчинної фракції (рис. 3)

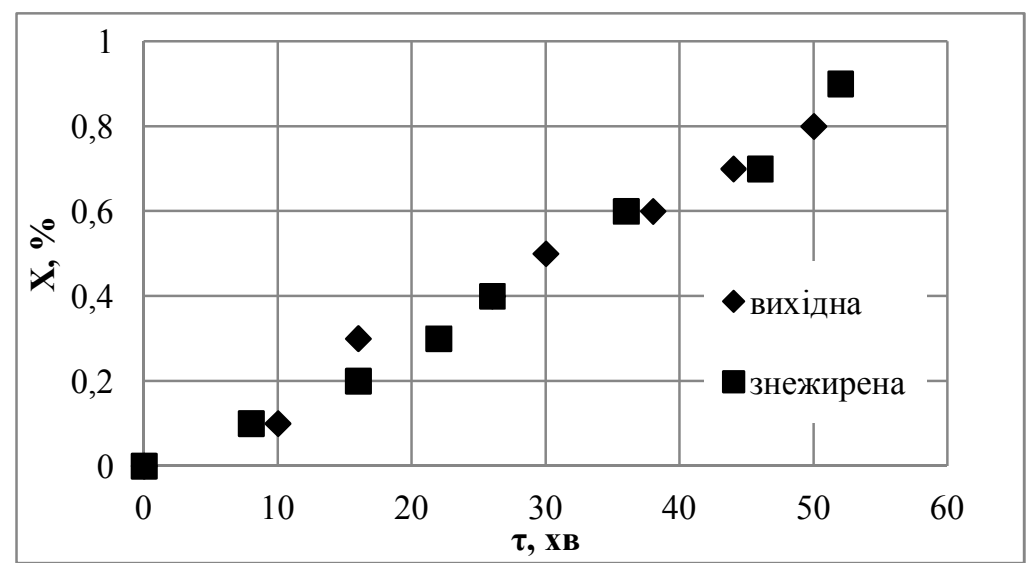

Рис. 3 - Кінетика вилучення водорозчинної фракції з макухи амаранту

Суттєвого впливу попереднього знежирення на кінетику екстрагування водорозчинних компонентів 3 макухи амаранту не виявлено.

Порівняння кінетики екстрагування лугорозчинної фракції в умовах дії мікрохвильового поля та в умовах традиційного підігріву до $40^{\circ} \mathrm{C}$ наведено на рис. 4. Питоме підведення енергії на процес складало $105 \ldots 110$ Вт/кг продукту.

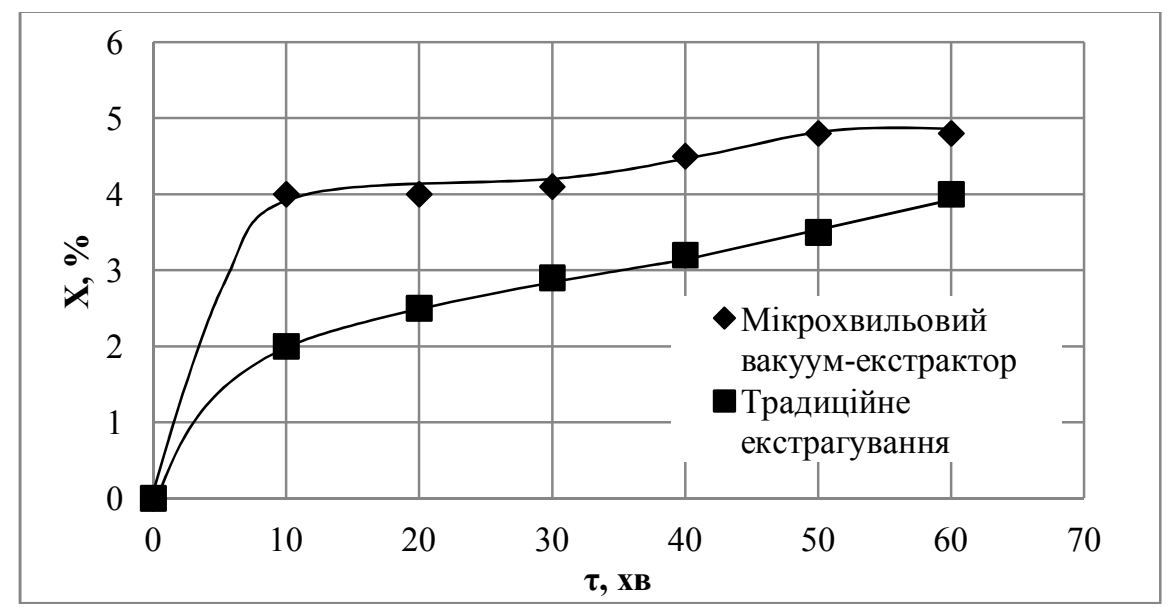

Рис. 4 - Вплив адресної доставки енергії на інтенсивність екстрагування білку та сухих речовин 3 макухи амаранту 
Встановлено, що у мікрохвильовому вакуум-екстракторі концентрація екстракту в перші 10 хвилин обробки до екстракту перейшло 83 \% вилучених сухих речовин. За традиційними технологіями екстрагування такий результат досягається протягом 60 хвилин. Таким чином, для вилучення такої ж кількості екстрактивних речовин, за 10 хвилин у мікрохвильовому екстракторі необхідно витратити енергії 72 кДж/кг екстракту, в той час як при традиційному енергопідведенні доведеться підвести 300...400 кДж/кг (в залежності від початкової температури сировини та екстрагенту та навколишнього середовища). Таким чином ефект адресної доставки енергії відкриває суттєві резерви до збільшення енергоефективності процесу екстрагування білку за макухи амарнту.

Свіжі яблучні вичавки, як фруктово-ягідна сировина, принципово відрізняються за властивостями та хімічним складом від відходів виробництва розчинної кави, або олії. Досліди проводились 3 водою в якості екстрагента, в мікрохвильовому вакуум-екстракторі за температури $35 \ldots 40{ }^{\circ} \mathrm{C}$ та тиску 11 КПа та 3 гідромодулями 1:6 та 1:4. Питоме підведення енергії складало 120 Вт/кг. Оскільки вологість сировини складає $79 . .82 \%$, використання високих гідромодулів недоцільне. Кінетичні криві екстрагування водорозчинних компонентів яблучних вичавок з різними гідромодулями наведено на рис. 5.

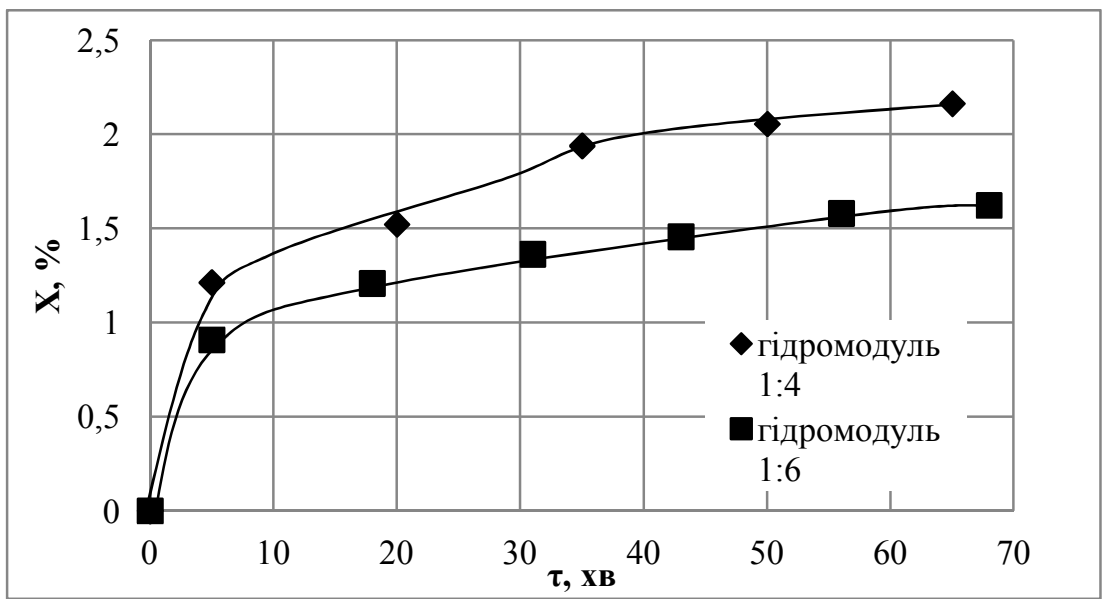

Рис. 5 - Кінетика екстрагування водорозчинної фракції з яблучних вичавок за зміною концентрації екстракту

Найбільше зростання концентрації сухих речовин в екстрактах спостерігається в перші п'ять хвилин процессу, але в цих точках вилучено близько 50\% від сухих речовин, що переходять до екстракту. Постійною контентрація екстракту стає після 60 хвилин обробки.

Про ефективність збільшення гідромодуля можна судити за вичерпанням твердої фази. Кінетика процессу наведена на рис. 6.

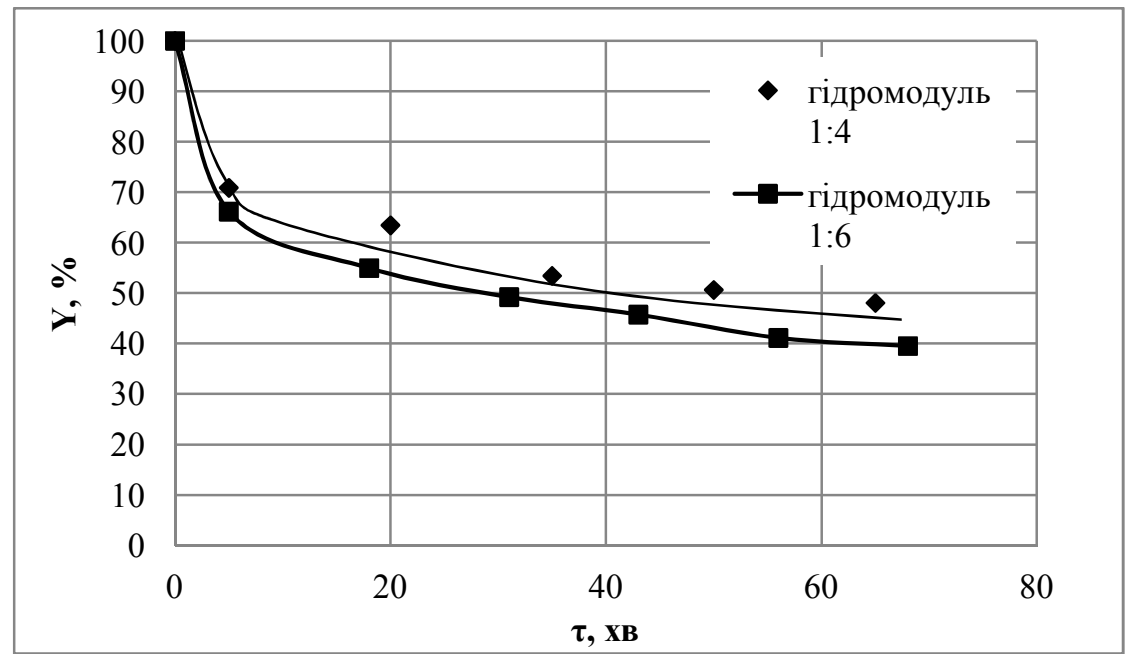

Рис. 6 - Кінетика екстрагування водорозчинної фракції з яблучних вичавок за вичерпанням твердої фази

Постійні питомі енерговитрати у дослідах зберігались за рахунок однакової маси води в екстракційній ємкості, пропорційно змінювалась маса твердої фази. Збільшення гідромодуля веде до збільшення рушійної 
сили процесу, проте при подальшому концентруванні екстракту витрати енергії на видалення більшої кількості екстрагенту також суттєво зростають. Крім того екстрагент вода поглинає енергію мікрохвильового поля, тому збільшення гідромодуля веде й до збільшення питомих витрат енергії на процес екстрагування. Таким чином, для визначення раціонального гідромодуля необхідно враховувати співвідношення рушійної сили процесу екстрагування, питомих енерговитрат на процес екстрагування, та енерговитрат на процес концентрування екстракту.

В результаті дослідів було вилучено до 46 \% від маси сухих речовин вичавок. Екстракт мав смак та аромат яблука, після концентрування та сушіння утворився продукт желеподібної консистенції.

Питомі енергетичні витрати склали $0,7 \ldots 0,8$ МДж/кг екстракту.

\section{Висновки}

Комбінування вакууму та адресної доставки енергії знаходить застосування у технологіях переробки відходів олійної та харчової промисловості, оскільки дозволяє проводити екстрагування за низьких температур. Встановлено значну інтенсифікацію екстрагування лугорозчинної фракції з макухи амаранту для вилучення білків у мікрохвильовому вакуум-екстракторі, зменшення питомих енерговитрат у $3 \ldots 5$ разів в порівнянні з традиційними технологіями.

Доцільність вилучення олій з кавового лушпиння та макухи амаранту потребує економічного обгрунтування і залежить від початкового вмісту олії у сировині.

У переробці яблучних вичавок інтенсифікація процесу екстрагування у мікрохвильовому вакуумекстракторі дозволяє вилучити більше $40 . .45$ \% сухих речовин та отримати високоякісний за органолептичними показниками пектиновмісний екстракт при низьких температурах, що запобігає руйнуванню біологічно активних сполук. Такий екстракт може бути використаний в технології приготування напоїв та джемів, конфітюрів.

\section{References}

1. Nigmatullina I. M., Agafonova S. V. (2019). Issledovaniye protsessa fermentativnogo gidroliza uglevodov vtorichnogo yablochnogo syr'ya [Investigation of the process of enzymatic hydrolysis of carbohydrates of secondary apple raw materials]. Vestnik molodezhnoy nauki. 4 (21). URL: https:/cyberleninka.ru/article/n/issledovanie-protsessa-fermentativnogo-gidroliza-uglevodov-vtorichnogoyablochnogo-syrya.

2. Burdo O.G., Terziyev S.G., Ruzhitskaya N.V., Makiyevskaya T.L. (2014). Protsessy pererabotki kofeynogo shlama [Coffee sludge processing processes]. K.: EnterPrint (in Russian).

3. Fedorov A.A., Antipova L.V. (2010). Primeneniye zhmykha iz semyan amaranta v proizvodstve kombinirovannykh myasnykh produktovyu [The use of cake from amaranth seeds in the production of combined meat products]. Izvestiya vuzov. Pishchevaya tekhnologiya. 4. 11-13 (in Russian).

4. Terziyev, S., Ruzhyts'ka, N., Syrotyuk, I., Akimov, O., Shcherbych, M. (2020). Innovatsiyni protsesy oderzhannya fitoekstraktiv i kontsentrativ dlya kharchovoyi, farmatsevtychnoyi ta parfumerno-kosmetychnoyi promyslovosti [Innovative processes for obtaining phytoextracts and concentrates for the food, pharmaceutical, perfume and cosmetics industries]. Scientific Works, 84(1). 73-78 (in Ukrainian). https://doi.org/10.15673/swonaft.v84i1.1873

5. Honcharov, D. S., Ruzhyts'ka, N. V., Akimov, O. V. (2020). Analiz zhyrnokyslotnoho skladu ekstraktiv ta oliy kavy [Analysis of the fatty acid composition of coffee extracts and oils]. Enerhiya. Biznes. Komfort : materialy rehion. nauk.-prakt. konf. Odesa: ONAKhT. 38-39 (in Ukrainian).

6. Naumenko, K.I., Cherno, N.K., Shatalova, D.M. (2021). Amarant - perspektyvne dzherelo otrymannya bilkovykh komponentiv [Amaranth is a promising source of protein components]. Zbirnyk tez dopovidey 81 -yi naukovoyi konferentsiyi vykladachiv akademiyi, Odesa: ONAKhT, 384 - 385 (inUkrainian).

7. Hulak, O.V., Polishchuk, H.Ye., Kalinina, H.P., Yanyuk, T.I. (2007). Amarantove boroshno - perspektyvna kharcho-va dobavka u vyrobnytstvi morozyva [Amaranth flour is a promising food additive in the production of ice cream]. Produkty $i$ ingrediyenty. 74 - 76 (in Ukrainian).

8. Egorov, B. V., Tsyundik, A. G., Orekhova, V. G. (2015). Perspektivy pererabotki i ispol'zovaniya yablochnykh vyzhimok [Prospects for the processing and use of apple pomace.]. Zernovi produkty $i$ kombikormy, 59(1). 38-43 (in Russian).

9. Gol'dberg, M. A. (2017). Osnovnyye napravleniya ispol'zovaniya yablochnykh vyzhimok [The main directions of using apple pomace]. Sbornik materialov 73-y studencheskoy nauchno-tekhnicheskoy konferentsii. Minsk : BNTU. 66-69 (in Russian).

10. Makarova, N.V., Eremeyeva, N.B., Davydova, Ya.V. (2020). S"yedobnaya upakovka iz otkhodov pererabotki yablok [Edible packaging from apple processing waste]. Vestnik KamchatGTU, 51. 26 - 33 (in Russian).

11. Chaldayev P.A., Svechnikov A.Yu. (2014). Primeneniye yablochnykh vyzhimok dlya proizvodstva produktov pitaniya [Application of apple pomace for food production]. Pishchevaya promyshlennost', 4. 40 - 41 (in Russian). 


\title{
INTENSIFICATION OF THE EXTRACTION PROCESS IN FOOD AND OILSEED PRODUCTIONS WASTE UTILIZATION TECHNOLOGIES
}

\author{
Terziyev S.H., Doctor of Engineering Science, Associate Professor, \\ Ruzhytska N.V., PhD, assistant, Shcherbych M.V., postgraduate student, Alhuri Yusef, PhD \\ Odessa National Academy of Food Technologies
}

\begin{abstract}
The article deals with the issues of waste utilization in the oilseed, food concentrate, and canning industries. It is proposed to use extraction technologies to extract valuable components that remain in waste after the manufacturing of the main product. The possibility of extracting oils from coffee husks and amaranth cake is considered. Extraction of water - and alkali-soluble fractions from Amaranth cake as a stage of extraction of valuable protein was also studied. Extraction of water-soluble components from fresh apple pomace - fruit and berry waste is considered. It is proposed to intensify the extraction process by supplying energy in the form of microwave radiation, which causes the phenomenon of barodiffusion in the structures of raw materials, and providing a boiling mode of the extractant, which organizes constant contact of fresh portions of the extractant with the raw material. To preserve thermolabile substances and prevent protein denaturation in the extractor, boiling is carried out in a vacuum. The results of extraction of oil and alcohol-soluble components from coffee husk and amaranth cake are shown. Kinetic curves of the extraction process of amaranth cake with water and an alkaline solution under the influence of a microwave field and vacuum are obtained. The kinetics of extraction of the alkali-soluble fraction from amaranth cake using targeted energy delivery and traditional energy delivery are compared. A significant intensification of the process is shown. The specific energy consumption of the process is determined. Kinetic curves of the extraction process of apple pomace with water at various hydraulic modules are obtained. The percentage of solid phase dry matter that passes to the extract is determined. Specific energy consumption for the extract production process is determined. The obtained product has the aroma of apples and obvious gelling properties.
\end{abstract}

Keywords: waste, amaranth cake, microwave extraction, apple pomace, vacuum

\section{Список використаної літератури}

1. Нигматуллина И. М., Агафонова С. В. Исследование процесса ферментативного гидролиза углеводов вторичного яблочного сырья. Вестник молодежной науки. 2019. №4 (21). URL: https://cyberleninka.ru/article/n/issledovanie-protsessa-fermentativnogo-gidroliza-uglevodov-vtorichnogoyablochnogo-syrya.

2. Бурдо О.Г., Терзиев С.Г., Ружицкая Н.В., Макиевская Т.Л. Процессы переработки кофейного шлама. К.: ЭнтерПринт, 2014. 228c.

3. Федоров А.А., Антипова Л.В. Применение жмыха из семян амаранта в производстве комбинированных мясных продуктовю. Известия вузов. Пищевая технология, 2010. № 4,. С. 11-13

4. Терзієв, С., Ружицька, Н., Сиротюк, І., Акімов, О., Щербич, М. Інноваційні процеси одержання фітоекстрактів і концентратів для харчової, фармацевтичної та парфумерно-косметичної промисловості. Наукові праці, 2020. Вип. 84(1), С. 73-78. https://doi.org/10.15673/swonaft.v84i1.1873

5. Гончаров Д. С. Аналіз жирнокислотного складу екстрактів та олій кави / Д. С. Гончаров, Н. В. Ружицька, О. В. Акімов. Енергія. Бізнес. Комфорт : матеріали регіон. наук.-практ. конф., Одеса, 20 груд. 2019 р., 2020. Одеса: ОНАХТ. С. 38-39

6. Науменко К.І., Черно Н.К., Шаталова Д.М. Амарант - перспективне джерело отримання білкових компонентів. Збірник тез доповідей 81-ї наукової конференції викладачів академії, Одеса: ОНАХТ, 2021, C. $384-385$.

7. Гулак О.В., Поліщук Г.С., Калініна Г.П., Янюк Т.І. Амарантове борошно - перспективна харчова добавка у виробництві морозива. Продукты и ингредиенты, 2007, С. 74 - 76.

8. Егоров Б. В., Цюндик А. Г., Орехова В. Г. Перспективы переработки и использования яблочных выжимок. Зернові продукти і комбікорми, 2015, Том 1 № 59. С.38-43

9. Гольдберг, М. А. Основные направления использования яблочных выжимок Сборник материалов 73-й студенческой научно-технической конференции. Минск : БНТУ, 2017. - С. 66-69.

10. Макарова Н.В., Еремеева Н.Б., Давыдова Я.В. Съедобная упаковка из отходов переработки яблок. Вестник КамчатГТУ, 2020, №51, С. 26 - 33.

11. Чалдаев П.А., Свечников А.Ю. Применение яблочных выжимок для производства продуктов питания. Пищевая промышленность, 2014, № 4, С. 40 - 41.

Отримано в редакцію 14.03.2021

Прийнято до друку 02.07.2021
Received 14.03.2021

Approved 02.07.2021 